\title{
Outbreaks of Edwardsiella ictaluri Infection in Ayu Plecoglossus altivelis in Japanese Rivers
}

\author{
Takamitsu Sakai $^{1 *}$, Takashi Kamaishi ${ }^{1}$, Motohiko Sano $^{1}$, Kozue Tensha $^{2}$, \\ Taeko Arima ${ }^{3}$, Yoshisuke lida ${ }^{4}$, Takahiro Nagai ${ }^{4,5}$, \\ Toshihiro Nakai ${ }^{5}$ and Takaji lida ${ }^{1}$ \\ ${ }^{1}$ National Research Institute of Aquaculture, Fisheries Research Agency, Minami-Ise, \\ Mie 516-0193, Japan \\ ${ }^{2}$ Inland Sea Division, Yamaguchi Prefectural Fisheries Research Center, \\ Aio-Futashima, Yamaguchi 754-0893, Japan \\ ${ }^{3}$ Tokyo Metropolitan Islands Area Research and Development Center of Agriculture, \\ Forestry and Fisheries, Minato, Tokyo 105-0022, Japan \\ ${ }^{4}$ Fisheries and Marine Technology Center, Hiroshima Prefectural Technology \\ Research Institute, Kure, Hiroshima 737-1207, Japan \\ ${ }^{5}$ Graduate School of Biosphere Science, Hiroshima University, \\ Higashi-Hiroshima, 739-8528, Japan
}

(Received August 29, 2008)

\begin{abstract}
From middle August to early October in 2007, mortalities in wild ayu Plecoglossus altivelis occurred in the rivers of Tokyo Metropolis, Yamaguchi Prefecture and Hiroshima Prefecture, Japan. Hemorrhagic ascites was observed in almost all the examined fish. Some fish showed reddening of body surface, anus or bases of fins and exophthalmos. A single species of bacteria was isolated from the kidney, spleen and ascites of all the examined fish and identified as Edwardsiella ictaluri. Pathogenicity against ayu of the bacterial isolates was demonstrated by experimental infections, with the $\mathrm{LD}_{50}$ being approximately $10^{4} \mathrm{CFU} /$ fish. The dead fish exhibited similar disease signs to those of naturally affected fish. From these results, it was concluded that the present mortality of wild ayu was caused by $E$. ictaluri infection. This is the first report on $E$. ictaluri infection of fish in Japan.
\end{abstract}

Key words: Edwardsiella ictaluri, Plecoglossus altivelis, hemorrhagic ascites, ayu

The ayu Plecoglossus altivelis is an osmerid fish with one-year life cycle and is one of the most popular freshwater fish species in Japan. Hatchery-produced juvenile ayu are annually released into local rivers for freshwater fisheries and sport fishing. According to the Japanese Statistics of Agriculture, Forestry and Fisheries Report in 2007 (http://www.maff.go.jp/www/info/ bunrui/bun06.html), approximately 6,000 tons of ayu were produced in 40 prefectures. Production value of ayu fisheries and farming accounts for one-third of the total value of the production of freshwater fisheries in Japan. Since natural migration of ayu is heavily disturbed by dams and other artificial barriers in the stream, both fisheries and sports fishing of this species can not exist without artificial releasing of the seedlings into rivers.

Farming industry of ayu has been suffering from serious damages due to various bacterial, fungal and parasitic diseases (Hatai and Ogawa ed., 2005). In contrast, there have been few reports on disease occurrences in wild population of ayu, with some exceptions such as bacterial cold-water disease by Flavobacterium psychrophilum (lida and Mizokami, 1996) and vibriosis by Vibrio cholerae non-O1 (Muroga et al., 1979). We report here a new bacterial disease occurred in ayu in the rivers of Tokyo Metropolis, Yamaguchi Prefecture and Hiroshima Prefecture, Japan, from August to October in 2007.

\footnotetext{
* Corresponding author

E-mail: tasakai@affrc.go.jp
} 


\section{Materials and Methods}

\section{Examination of diseased fish and bacterial isolation}

Moribund or dead ayu were sampled from rivers in Tokyo, Yamaguchi and Hiroshima. Following external and internal observations of the fish, bacterial isolation from the kidneys or spleens was performed using TryptoSoya agar (TSA; Nissui, Japan) or nutrient agar (NA; Nissui), and the plates were incubated at $25^{\circ} \mathrm{C}$. The smears of the kidneys, spleens or livers from the fish on glass slides were stained by Gram's method or with methylene blue.

\section{Histopathological observation}

Heart, liver, spleen, kidney, muscle and digestive tract were dissected from three moribund ayu sampled in Yamaguchi Prefecture, and fixed in Davidson's solution (Bell and Lightner, 1988). Each sample was embedded in paraffin. Two sets of sections were cut at 3-4 $\mu \mathrm{m}$ from each tissue and stained with either hematoxylineosin or May-Grünwald-Giemsa.

\section{Experimental infection}

Two representative bacterial isolates, FPC1091 in Yamaguchi Prefecture and $\mathrm{PH}-0744$ in Hiroshima Prefecture, were used in the pathogenicity test. Experimental infection with FPC1091 was performed using ayu (average body weight; $65.6 \mathrm{~g}$ ) cultured in a farm in Yamaguchi Prefecture. For $\mathrm{PH}-0744$, two stocks of ayu (Nagai et al., 2004), an amphidromous stock (average body weight; $17.8 \mathrm{~g}$ ) and domesticated stock (average body weight; $22.7 \mathrm{~g}$ ), maintained in Fisheries and Marine Technology Center, Hiroshima Prefectural Technology Research Institute were used. Bacteria were cultured on NA at $23^{\circ} \mathrm{C}$ for $96 \mathrm{~h}$ (FPC1091) or on TSA at $20^{\circ} \mathrm{C}$ for $48 \mathrm{~h}(\mathrm{PH}-0744)$.

Table 1. Epidemiological data on the disease of wild ayu in rivers in Tokyo Metropolis, Yamaguchi and Hiroshima Prefectures, Japan.

\begin{tabular}{|c|c|c|c|}
\hline \multirow{3}{*}{ Period } & \multicolumn{3}{|c|}{ Location } \\
\hline & \multirow{2}{*}{$\begin{array}{l}\text { Tokyo Metropolis } \\
\text { Middle August }\end{array}$} & Yamaguchi Prefecture & \multirow{2}{*}{$\begin{array}{l}\text { Hiroshima Prefecture } \\
\text { Middle September-early } \\
\text { October }\end{array}$} \\
\hline & & $\begin{array}{l}\text { Early September-early } \\
\text { October }\end{array}$ & \\
\hline Water temperature & $26^{\circ} \mathrm{C}$ & $26^{\circ} \mathrm{C}-23^{\circ} \mathrm{C}$ & $26^{\circ} \mathrm{C}-20^{\circ} \mathrm{C}$ \\
\hline $\begin{array}{l}\text { The number of dead ayu per day } \\
\text { (cumulative number) }\end{array}$ & Unknown & Approximately 35 (1400) & Unknown \\
\hline $\begin{array}{l}\text { Abnormal sign or death in the other } \\
\text { fish (number of fish) }\end{array}$ & Unknown & $\begin{array}{l}\text { Pale chub Zacco platypus; } \\
\text { dead (2), moribund (1) }\end{array}$ & Unknown \\
\hline River water quality & Normal & Normal & Unknown \\
\hline $\begin{array}{l}\text { Appearance of upstream migration } \\
\text { of amphidromous ayu }\end{array}$ & Good & Usual & Usual \\
\hline Fish released in the river & $\begin{array}{l}\text { Ayu, ginbuna Carassius gibelio } \\
\text { langsdorfi, Japanese eel Anguilla } \\
\text { japonica, Japanese dace Tribolodon } \\
\text { hakonensis, Rainbow trout } \\
\text { Oncorhynchus mykiss, Masu } \\
\text { salmon Oncorhynchus masou } \\
\text { and whitespotted char Salvelinus } \\
\text { leucomaenis }\end{array}$ & Ayu and Masu salmon & Ayu and Japanese eel \\
\hline Fish cultured at the upper river site & $\begin{array}{l}\text { Ayu, rainbow trout, Masu salmon, } \\
\text { whitespotted char }\end{array}$ & $\begin{array}{l}\text { Ayu, rainbow trout and } \\
\text { Masu salmon }\end{array}$ & Masu salmon \\
\hline \multicolumn{4}{|l|}{ Clinical data of the diseased ayu } \\
\hline $\begin{array}{l}\text { Total length (body weight) of the } \\
\text { affected ayu }\end{array}$ & $125-201 \mathrm{~mm}(13-67 \mathrm{~g})$ & 159-267 mm (34-205 g) & $190 \mathrm{~mm} *(95 \mathrm{~g})$ \\
\hline $\begin{array}{l}\text { External clinical features } \\
\text { (The number of fish/examined) }\end{array}$ & $\begin{array}{l}\text { Exophthalmos and reddening of } \\
\text { head }(1 / 6) \\
\text { Abdominal distension and redden- } \\
\text { ing of anus }(1 / 6)\end{array}$ & $\begin{array}{l}\text { Reddening of anus }(7 / 15) \\
\text { Reddening of body surface } \\
\text { and base of fins }(5 / 15) \\
\text { Pale of gills }(4 / 8) \\
\text { Exophthalmos }(1 / 15)\end{array}$ & $\begin{array}{l}\text { Protruded lesion on the } \\
\text { body surface }(1 / 1) \\
\text { Reddening of gonad (1/1) }\end{array}$ \\
\hline $\begin{array}{l}\text { Internal clinical features } \\
\text { (The number of fish /examined) }\end{array}$ & Hemorrhagic ascites $(6 / 6)$ & $\begin{array}{l}\text { Hemorrhagic ascites }(5 / 10) \\
\text { Softening kidney }(4 / 10) \\
\text { Hypertrophy of kidney }(3 / 10) \\
\text { Discoloration of liver }(2 / 10)\end{array}$ & Hemorrhagic ascites (1/1) \\
\hline
\end{tabular}

\footnotetext{
* Body length
} 
Two groups of fish ( $\mathrm{n}=10)$ was intraperitoneally (ip) injected with FPC1091 at a dose of $3.2 \times 10^{8}$ or $3.2 \times 10^{5}$ CFU/0.1 mL/fish. The injected fish were held in aerated flow-through tanks at $20^{\circ} \mathrm{C}$. In the case of $\mathrm{PH}-0744$, three groups of fish ( $n=20$ or 21 each) were ip-injected with doses of $6.5 \times 10^{6}, 6.5 \times 10^{4}$ or $6.5 \times 10^{2}$ CFU/0.1 mL/fish. The injected fish were held in aerated flow-through tanks at $17.5^{\circ} \mathrm{C}$. In both experimental infections, control fish were ip-injected with $0.1 \mathrm{~mL}$ of sterile saline. Mortality was daily recorded for about 2 weeks. Bacterial re-isolation was performed with kidneys of dead fish to confirm the cause of death.

\section{Results}

\section{Epidemiological features and bacterial isolation}

From summer (August) to fall (October) in 2007, moribund or dead ayu were observed in each river in Tokyo Metropolis, Yamaguchi and Hiroshima Prefectures, Japan. The epidemiological features and the disease signs of affected ayu are summarized in Table 1. The disease occurred at a water temperature of around $26^{\circ} \mathrm{C}$. Fish with abnormal swimming or at moribund state were caught by net or found in area of slow-
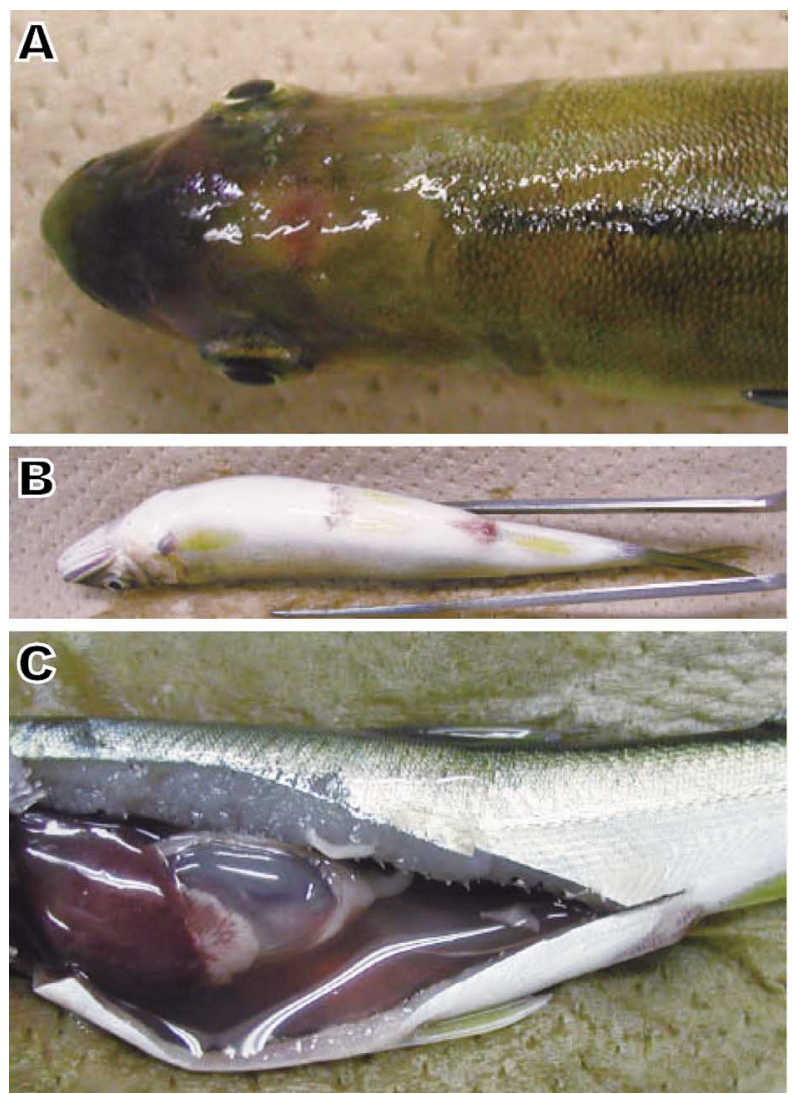

Fig. 1. Clinical signs of ayu sampled in Tokyo Metropolis. (A) Exophthalmos, (B) Abdominal distension and reddening of the anus, $(\mathrm{C})$ Bloody (hemorrhagic) ascites in the peritoneal cavity. flowing water in each river. A mass mortality due to the disease was confirmed in Yamaguchi Prefecture. The disease was observed in both stocked and wild fish groups. Two dead and one moribund pale chub Zacco platypus were observed in the river, but these samples were not applied to the tests because of the staleness. No other fish species showing abnormal signs was found in any rivers. No abnormality was found in the water quality of the rivers during the disease occurrence.

Sampled moribund or dead fish for the tests ranged from 125 to $267 \mathrm{~mm}$ in total length and from 13 to $205 \mathrm{~g}$ in body weight. Distinctive external lesions were not observed in many samples. Exophthalmos, abdominal distension, or reddening of anus, body surface or bases of fins was shown in some samples from Tokyo Metropolis and Yamaguchi Prefecture (Fig. 1). Protruded lesion on the body surface and reddening of gonad were shown in a sample from Hiroshima Prefecture (Fig. 2). Bloody (hemorrhagic) ascites in the peritoneal cavity was formed in almost all of the samples (Fig. 1C). Softening or hypertrophy of the kidney was observed in several fish. Many rod-shaped bacteria were observed in the smear preparations from the kidney and spleen of almost all examined fish.

A Gram-negative, facultatively anaerobic, cytochrome oxidase-negative, short rod bacterium was dominantly isolated from all the samples collected in three
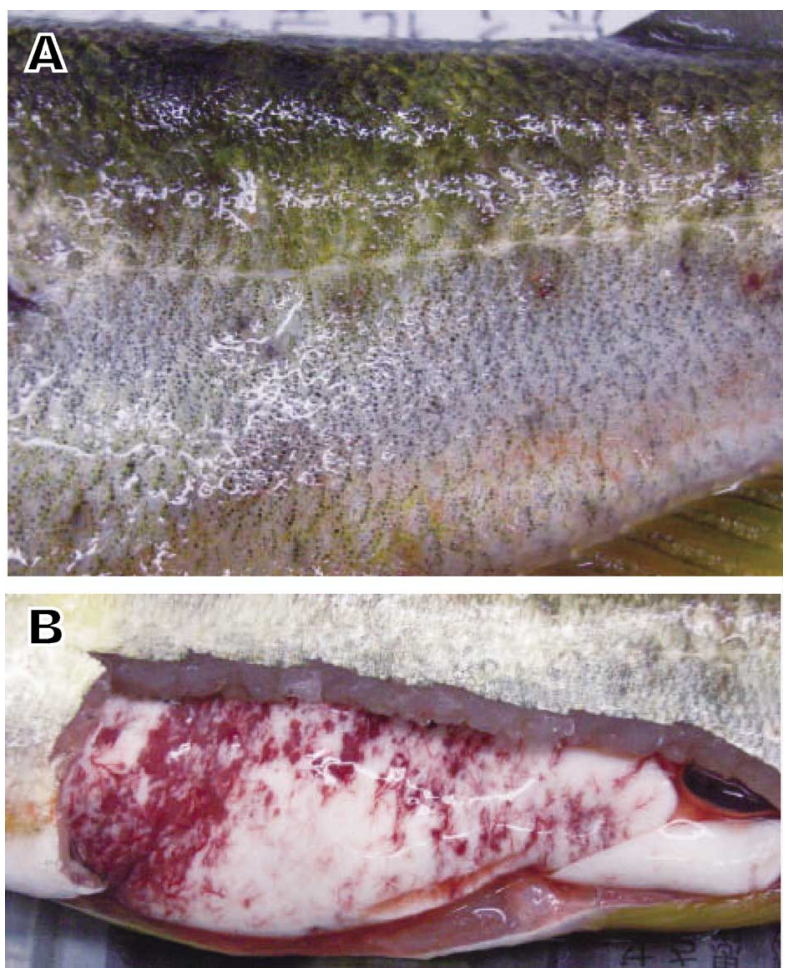

Fig. 2. Clinical signs of ayu sampled in Hiroshima Prefecture. (A) Protruded lesion on the body surface, (B) Reddening of the gonad. 
locations. The smooth and white colonies were visible on TSA after 2-3 days. In other phenotypic and genetic characterization tests, all isolates showed same characteristics and the bacterium was identified as Edwardsiella ictaluri. The results of detailed characterization tests on the present bacterium and comparison with the reported $E$. ictaluri strains are described in Nagai et al. (2008).

\section{Histopathological observation}

Short or long rod-shaped bacteria were observed in the heart or pericardium in all examined fish (Fig. 3A). Two of three fish exhibited pericarditis (Fig. 3B). Severe hemorrhage was observed in the pericardial cavity in one fish. Short rod-shaped bacteria were observed in the kidney of two of three fish (Fig. 3C). An increasing number of leukocytes in the blood, disruption of sheath in the spleen and focal death of hepatocyte in the liver were observed in one fish. Short rod-shaped bacteria were observed in these sites (Fig. 3D). The stomach, gills and brain of all samples exhibited no pathological change and bacteria were not found in these organs.

\section{Pathogenicity of the isolated bacterium}

Cumulative mortality of ayu injected with the strain FPC1091 isolated in Yamaguchi Prefecture is shown in Table 2. In the group injected with $3.2 \times 10^{8} \mathrm{CFU}$, all fish died within 3 days after the challenge. Deaths in the group injected with $3.2 \times 10^{5}$ CFU were observed from 5 days after the challenge. All dead fish showed reddening of body surface, anus or bases of fins, or hemorrhage in the peritoneal cavity. The bacterium was re-isolated from the kidney of all dead fish and identified as the inoculated bacteria by the colony morphology and other characteristics described in Nagai et al. (2008). Although one fish of the control group injected with sterile saline died after 8 days, no bacterium was isolated from this fish.

Cumulative mortalities of amphidromous and domesticated stocks injected with the strain $\mathrm{PH}-0744$ isolated in Hiroshima Prefecture are shown in Table 3. The cumulative mortality rates of the high-, mediumand low-dose groups of amphidromous fish were $100 \%$, $100 \%$ and $15 \%$, respectively. In the challenge test with domesticated fish, cumulative mortality rates of the high-, medium- and low-dose groups were 100\%, $81 \%$ and $5 \%$, respectively. The median lethal dose $\left(L_{50}\right)$
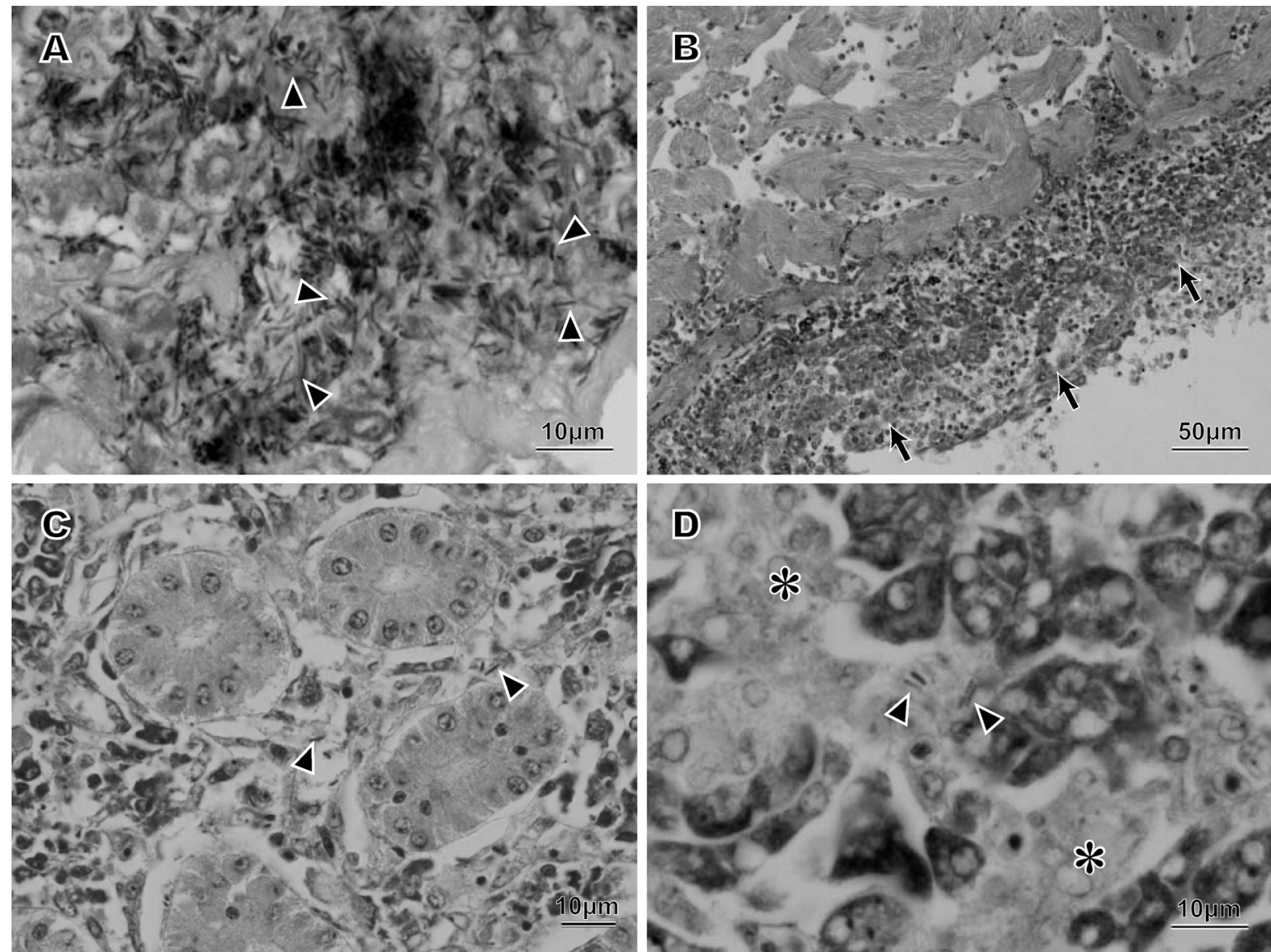

Fig. 3. Histopathology of ayu sampled in Yamaguchi Prefecture. Pericardium (A and B), kidney (C) and liver (D). Note bacteriumlike rods (arrowheads), pericarditis (arrow) and focal death of hepatocyte (*). May-Grünwald-Giemsa staining 
Table 2. Cumulative mortality of ayu challenged by intraperitoneal injection with a bacterial strain (FPC1091) isolated in Yamaguchi Prefecture

\begin{tabular}{cc}
\hline $\begin{array}{c}\text { Injection dose } \\
(\mathrm{CFU} / \text { fish })\end{array}$ & $\begin{array}{c}\text { No. of dead fish } \\
\text { /challenged fish }\end{array}$ \\
\hline $3.2 \times 10^{8}$ & $10 / 10$ \\
$3.2 \times 10^{5}$ & $7 / 10$ \\
Control & $1 / 10^{*}$ \\
\hline
\end{tabular}

*No bacterium was isolated from the dead fish.

Table 3. Cumulative mortality of ayu of domesticated and amphidromous stocks challenged by intraperitoneal injection with a bacterial strain $(\mathrm{PH}-0744)$ isolated in Hiroshima Prefecture

\begin{tabular}{lcc}
\hline Test fish (ayu) & $\begin{array}{c}\text { Injection dose } \\
\text { (CFU/fish) }\end{array}$ & $\begin{array}{c}\text { No. of dead fish/ } \\
\text { challenged fish }\end{array}$ \\
\hline & $6.5 \times 10^{6}$ & $21 / 21$ \\
Amphidromous stocks & $6.5 \times 10^{4}$ & $20 / 20$ \\
& $6.5 \times 10^{2}$ & $3 / 20$ \\
& Control & $0 / 20$ \\
\hline \multirow{5}{*}{ Domesticated stocks } & $6.5 \times 10^{6}$ & $20 / 20$ \\
& $6.5 \times 10^{4}$ & $17 / 21$ \\
& $6.5 \times 10^{2}$ & $1 / 20$ \\
& Control & $0 / 20$ \\
\hline
\end{tabular}

was calculated as $1.3 \times 10^{4} \mathrm{CFU} /$ fish by the method of Reed and Muench (1938). Most of the dead fish showed the clinical signs similar to those observed in naturally affected fish. The bacterium was re-isolated from the kidney of all dead fish and all survivors of the medium-dose group of domesticated fish. Rates of the re-isolation in survivors of the low-dose groups of amphidromous and domesticated fish were $41 \%$ and $58 \%$, respectively. No fish of each control group died during the experiment.

\section{Discussion}

A variety of bacterial diseases have been reported in cultured and wild ayu in Japan. These include vibriosis caused by Vibrio anguillarum (Muroga and Egusa, 1967), V. cholerea non O-1 (Muroga et al., 1979) or V. ordalii (Muroga et al., 1986), motile aeromonad disease by Aeromonas hydrophila (Jo and Ohnishi, 1980), bacterial gill disease by F. branchiophilum (Miyazaki and Jo, 1986), streptococcicosis by Streptococcus iniae (Ugajin, 1981; Kitao et al., 1981), bacterial hemorrhagic ascites (BHA) by Pseudomonas plecoglossicida (Nakatsugawa and lida, 1996; Wakabayashi et al., 1996), bacterial cold-water disease by F. psychrophilum (Wakabayashi et al., 1994; lida and Mizokami, 1996), and bacterial kidney disease by Renibacterium salmoninarum (Nagai and lida, 2002). The disease signs in the present disease are different from those of these reported diseases. Although hemorrhagic ascites is known as a notable dis- ease sign of BHA (Wakabayashi et al., 1996), hemorrhage in acites in the present disease is much less than that in BHA. The bacterium isolated in this study was Gram-negative and cytochrome oxidase-negative. Since all of the above mentioned diseases are caused by cytochrome oxidase-positive bacteria, the present bacterium can be differentiated from them. Our further study revealed that the present bacterium was identified as Edwardsiella ictaluri and showed the same characteristics in the biochemical tests and analyses of genes for 16S rRNA, a type1 fimbrial (etfA) and a heat shock protein gene (dnaJ) (Nagai et al., 2008).

E. ictaluri infection is well known as enteric septicemia of catfish (ESC) (Plumb, 1999). The affected channel catfish Ictalurus punctatus show pale gills, exophthalmos, cutaneous ulcers, hemorrhage at the base of fins, and inflammation of skin, the lower jaw and the operculum. The internal clinical signs include hemorrhagic ascites, hypertrophy of the kidney and spleen, dark reddening of the spleen, inflammation in the adipose tissue, peritoneum and intestine, and/or congestive mottle of the liver. In the present study, the affected ayu showed clinical signs similar to the ESC, i.e. pale gills, exophthalmos, reddening of the base of fins, hemorrhagic ascites and/or hypertrophy of the kidney. Among these signs, hemorrhagic ascites seem to be a pathognomonic sign in the ayu affected with E. ictaluri, since it was observed in many naturally or experimentally affected fish. Plumb (1999) described that the most severely damaged organs in E. ictaluri-infected catfish are the liver and spleen. Miyazaki and Plumb (1985) observed small foci of necrosis involving both hapatocytes and pancreatic cells in the liver and necrosis of sheath in the spleen of naturally infected channel catfish. Pathological changes in the liver and spleen were also observed in one out of three moribund ayu. No pathological changes were described in the heart of affected channel catfish, whereas two out of three ayu exhibited the pericarditis. The pericarditis may be unique in $E$. ictaluri infection of ayu.

$E$. ictaluri has caused ESC in ictalurids such as channel catfish, blue catfish $I$. furcatus, white catfish Ameiurus catus, brown bullhead $A$. nebulosus, walking catfish Clarias batrachus and striped catfish Pangasius hypophthalmus in the United States (Hawke et al., 1981; Plumb, 1999), Vietnam (Ferguson et al., 2001; Crumlish et al., 2002), Thailand (Kasornchandra et al., 1987) and Indonesia (Yuasa et al., 2003). Although naturally occurring disease has also been reported in some freshwater ornamental species, i.e. rosy barbs Puntius conchonius (Humphrey et al., 1986), danio Danio devario (Waltman et al., 1985), and green knife fish Eigemannia virescens (Plumb, 1999), or farmed rainbow trout Oncorhynchus mykiss (Keskın et al., 2004), catfish is specifically susceptible to E. ictaluri (Plumb, 1999). Stanley et al. (1994) reported that the $\mathrm{LD}_{50}$ values of the 
virulent strains were $10^{3}-10^{5} \mathrm{CFU} /$ fish in ip-injected channel catfish. We showed that the strains $\mathrm{PH}-0744$ and FPC1091 isolated from ayu were pathogenic to ayu, and $\mathrm{LD}_{50}$ of the strain $\mathrm{PH}-0744$ was $1.3 \times 10^{4} \mathrm{CFU} /$ fish, indicating that ayu has E. ictaluri-susceptibility comparable to channel catfish. Further pathological studies should be performed in order to compare the susceptibility between catfish and ayu. From these results, the present study is the first report on $E$. ictaluri infection in Japan and also as a natural outbreak of the disease in wild non-ictalurids.

The disease outbreaks of wild ayu in 2007 were found only in three locations in Japan. However, special concern is that the disease will be epidemic in Japan. To prevent further spread of the disease, it is important to find the affected fish at early stages of outbreak and to stop transporting affected fish to the disease-free areas. For this purpose, the simple and rapid diagnostic method for the disease should be developed.

\section{References}

Bell, T. A. and D. V. Lightner (1988): Techniques. In "A handbook of normal penaeid shrimp histology". World Aquaculture Society, Banton Rouge, LA. pp. 2-6.

Crumlish, M., T. T. Dung, J. F. Turnbull, N. T. N. Ngoc and H. W. Ferguson (2002): Identification of Edwardsiella ictaluri from diseased freshwater catfish, Pangasius hypophthalmus (Sauvage), cultured in the Mekong Delta, Vietnam. J. Fish Dis., 25, 733-736.

Ferguson, H. W., J. F. Turnbull, A. Shinn, K. Thompson, T. T. Dung and M. Crumlish (2001): Bacillary necrosis in farmed Pangasius hypophthalmus (Sauvage) from the Mekong Delta, Vietnam. J. Fish Dis., 24, 509-513.

Hatai, K. and K. Ogawa (ed.) (2005): Ayu. In "New atlas of fish diseases". Midori shobou, Tokyo, pp. 51-71. (In Japanese)

Hawke, J. P., A. C. McWhorter, A. G. Steigerwalt and D. J. Brenner (1981): Edwardsiella ictaluri sp. nov., the causative agent of enteric septicaemia of catfish. Int. J. Syst. Bacteriol., 31, 396-400.

Humphrey, J. D., C. Lancaster, N. Gudkovs and W. McDonald (1986): Exotic bacterial pathogens Edwardsiella tarda and Edwardsiella ictaluri from imported ornamental fish Beta splendens and Puntius conchonius, respectively: isolation and quarantine significance. Aust. Vet. J., 63, 369-371.

lida, Y. and A. Mizokami (1996): Outbreaks of coldwater disease in wild ayu and pale chub. Fish Pathol., 31, 157164.

Jo, Y. and K. Ohnishi (1980): Aeromonas hydrophila isolated from cultured ayu. Fish Pathol., 15, 1-6. (In Japanese with English abstract)

Kasornchandra, J., W. A. Rogers and J. A. Plumb (1987): Edwardsiella ictaluri from walking catfish, Clarias batrachus L., in Thailand. J. Fish Dis., 10, 137.

Keskın, O., S. Seçer, M. İzür, S. Türkyilmaz and R. S. Mkakosya (2004): Edwardsiella ictaluri infection in rainbow trout (Oncorhynchus mykiss). Turk. J. Vet. Anim. Sci., 28,
$649-653$.

Kitao, T., T. Aoki and R. Sakoh (1981): Epizootic caused by $\beta$ haemolytic Streptococcus species in cultured freshwater fish. Fish Pathol., 15, 301-307.

Miyazaki, T and J. A. Plumb (1985): Histopathology of Edwardsiella ictaluri in channel catfish, Ictalurus punctatus (Raifinesque). J. Fish Dis., 8, 389-392.

Miyazaki, T and Y. Jo (1986): A histopathological study on bacterial gill disease of the ayu. Fish Pathol., 21, 207-208. (In Japanese with English abstract)

Muroga, K. and S. Egusa (1967): Vibrio anguillarum from an endemic disease of ayu in Lake Hamana. Bull. Japan. Soc. Sci. Fish., 33, 636-640.

Muroga, K., S. Takahashi, H. Yamanoi and M. Nishibuchi (1979): Non-cholerae vibrio isolated from diseased ayu. Bull. Japan. Soc. Sci. Fish., 45, 829-834.

Muroga, K., Y. Jo and K. Masumura (1986): Vibrio ordalii isolated from diseased ayu (Plecoglossus altivelis) and rockfish (Sebastes shlegell). Fish Pathol., 21, 239-243. (In Japanese with English abstract)

Nagai, T and Y. lida (2002): Occurrence of bacterial kidney disease in cultured ayu. Fish Pathol., 37, 77-81.

Nagai, T., E. Iwamoto, T. Sakai, T. Arima, K. Tensha, Y. lida, T. lida and T. Nakai (2008): Characterization of Edwardsiella ictaluri isolated from wild ayu Plecoglossus altivelis in Japan. Fish Pathol., 43, 158-163.

Nagai, T., T. Tamura, Y. lida and T. Yoneji (2004): Differences in susceptibility to Flavobacterium psychrophilum among three stocks of ayu Plecoglossus altivelis. Fish Pathol., 39, 159-164.

Nakatsugawa, T. and Y. lida (1996): Pseudomonas sp. isolated from diseased ayu, Plecoglossus altivelis. Fish Pathol., 31, 221-227. (In Japanese with English abstract)

Plumb, J. A. (1999): Catfish bacterial diseases. In "Health maintenance and principal microbial diseases of cultured fishes". lowa State University Press, lowa, pp. 187-194.

Reed, L. J. and H. Muench (1938): A simple method of estimating 50 percent endpoints. Am. J. Hyg., 27, 493-497.

Stanley, L. A., J. S. Hudson, T. E. Schwedler and S. S. Hayasaka (1994): Extracellular products associated with virulent and avirulent strains of Edwardsiella ictaluri from channel catfish. J. Aquat. Anim. Health, 6, 36-43.

Ugajin, M (1981): Studies on Streptococcus sp. as a causative agent of an epizootic among the cultured ayu (Plecoglossus altivelis) in Tochigi Prefecture, Japan, 1980. Fish Pathol., 16, 119-127. (In Japanese with English abstract)

Wakabayashi, H., T. Toyama and T. lida (1994): A study on serotyping of Cytophaga psychrophila isolated from fishes in Japan. Fish Pathol., 29, 101-104.

Wakabayashi, H., K. Sawada, K. Ninomiya and E. Nishimori (1996): Bacterial hemorrhagic ascites of ayu caused by Pseudomonas sp. Fish Pathol., 31, 239-240. (In Japanese with English abstract)

Waltman, W. D., E. B. Shotts and V. S. Blazer (1985): Recovery of Edwardsiella ictaluri from danio (Danio devario). Aquaculture, 46, 63-66.

Yuasa, K., E. B. Kholidin, N. Panigoro, and K. Hatai (2003): First isolation of Edwardsiella ictaluri from cultured striped catfish Pangasius hypophthalmus in Indonesia. Fish Pathol., 38, 181-183. 